2011

\title{
Involuntary Creditors and Corporate Bankruptcy
}

Stephanie Ben-Ishai

Osgoode Hall Law School of York University, sbenishai@osgoode.yorku.ca

Stephen J. Lubben

Follow this and additional works at: http://digitalcommons.osgoode.yorku.ca/all_papers

\section{Repository Citation}

Ben-Ishai, Stephanie and Lubben, Stephen J., "Involuntary Creditors and Corporate Bankruptcy" (2011). All Papers. Paper 8.

http://digitalcommons.osgoode.yorku.ca/all_papers/8

This Working Paper is brought to you for free and open access by the Research Papers, Working Papers, Conference Papers at Osgoode Digital

Commons. It has been accepted for inclusion in All Papers by an authorized administrator of Osgoode Digital Commons. 

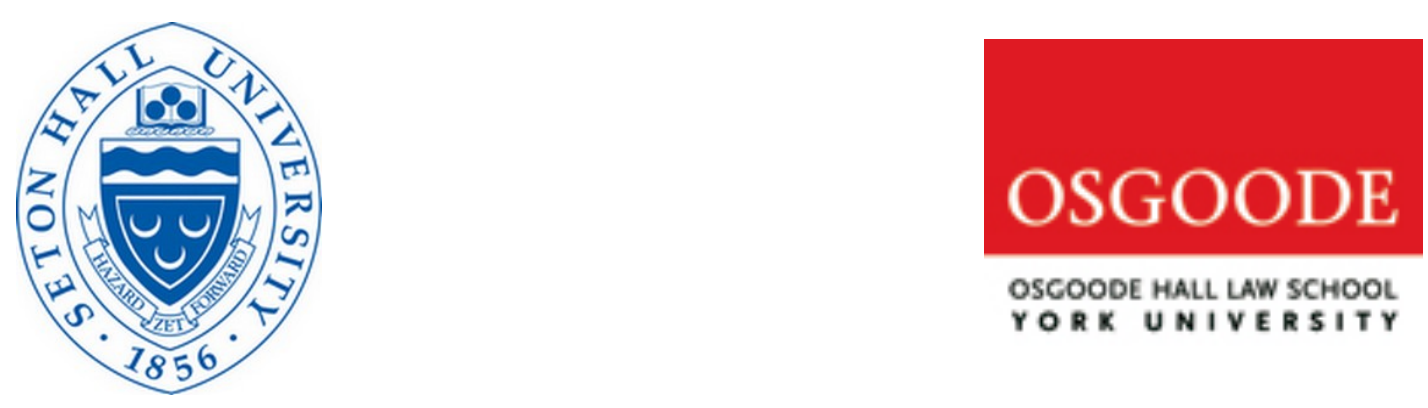

OSCOODE HALL LAW SCHOOL YORK UNIVERSITY

\title{
Involuntary Creditors and Corporate Bankruptcy
}

\author{
Stephanie Ben-Ishai
}

$\&$

Stephen J. Lubben

Draft Date: Tuesday, October 4, 2011 


\section{Involuntary Creditors and Corporate Bankruptcy}

\section{Stephanie Ben-Ishai and Stephen Lubben*}

The problem of involuntary creditors in corporate bankruptcy has been long recognized, with little actual effort expended toward solving the matter. ${ }^{1}$ Instead, the issue of tort, environmental, and tax creditors is typically acknowledged and the swept to the side by observing, "they should have a priority." ${ }^{2}$ No effort is actually made to give them a priority - although tax creditors typically already have a priority in both the United States and Canada ${ }^{3}$ - rather the observation simply removes an annoying problem with the larger theoretical point being made about corporate bankruptcy. ${ }^{4}$

Moreover, the repeated use of this tactic ignores the ways in which corporate bankruptcy has changed over the years, rendering even this solution of limited value. In particular, the growth of secured credit means that a priority claim, which simply bumps the creditor to the front of a large group of unpaid unsecured creditors, is little more than a token, with no real value. ${ }^{5}$ And more importantly, the trend of selling the corporate debtor's assets before consideration of a reorganization plan means that even the limited power that a priority creditor has will often be

Associate Professor, Osgoode Hall Law School.

Daniel J. Moore Professor of Law, Seton Hall University School of Law. Many thanks for the helpful comments received at the 2011 Annual Meeting of the European Law and Economics Association, and from Rachel Godsill and Régis Blazy. Ashley Butts, of Osgoode Hall, was the indispensible research assistant on this project.

1 See Lucian Arye Bebchuk \& Jesse M. Fried, "The Uneasy Case for the Priority of Secured Claims in Bankruptcy" (1996) 105 Yale L.J. 857 at 883 ("It is by now a familiar point in the law review and finance literature that according full priority to secured claims permits a firm to divert value from its tort creditors.").

$2 \quad$ Robert Rasmussen, "Resolving Transnational Insolvencies Through Private Ordering" (2000) 98 Mich. L. Rev. 2252 at 2269. See also Barry E. Adler, "A World Without Debt” (1994) 72 Wash. U.L.Q. 811 at 826; Kathryn R. Heidt, "Cleaning Up Your Act: Efficiency Considerations in the Battle for the Debtor's sAssets in Toxic Waste Bankruptcies" (1988) 40 Rutgers L. Rev. 819 at 851-63; Note, "Switching Priorities: Elevating the Status of Tort Claims in Bankruptcy in Pursuit of Optimal Deterrence" (2003) 116 Harv. L. Rev. 2541 at 2562; Hanoch Dagan, "Restitution in Bankruptcy: Why All Involuntary Creditors Should Be Preferred" (2004) 78 Am. Bank. L.J. 247 at 277.

3 This is not always so, for example, in Australia, the taxing authority has a general unsecured claim, coupled with strong rights against directors who fail to act in response to growing financial distress.

4 Paul Halpern et al., "An Economic Analysis of Limited Liability in Corporation Law" (1980) 30 U.T.L.J. 117 at $117-18$.

$5 \quad$ For a discussion of the growth of secured creditor power in US chapter 11 cases, see Douglas G. Baird \& Robert K. Rasmussen, "Private Debt and the Missing Lever of Corporate Governance" (2006) 154 U. Pa. L. Rev. 1209 at 1236-37. See also Ronald J. Mann, "Explaining the Pattern of Secured Credit" (1997) 110 Harv. L. Rev. 625 at 629; Elizabeth Warren \& Jay Lawrence Westbrook, "Contracting Out of Bankruptcy: An Empirical Intervention" (2005) 118 Harv. L. Rev. 1197 at 1222. 
focused in the wrong place. ${ }^{6}$ In particular, once the debtor's assets are sold, powers to vote on a plan are of little import in a case that could just as easily be resolved by liquidation under either the BIA, in Canada, or chapter 7, in the United States.

In this paper we focus on the particular concern that the preference for quick sales over traditional reorganization cases might allow the debtor's management to work with secured lenders to extract assets from the debtor in a way that would not be possible in a "normal" bankruptcy case. In particular, we examine how a quick sale can be used to cleanse assets of their association with environmental claims. ${ }^{7}$

We also consider how the insolvency systems in our respective countries might adapt to address this problem. Ultimately, the best protection for involuntary creditors, including environmental creditors, is to maximize the value of the debtor's assets. That counsels for improving stakeholders' ability to monitor the sale process and ensure that the sale process in not rushed for the sole benefit of senior creditors.

Throughout the paper we examine the issue of quick sales and involuntary creditors in both the United States and Canada. These two economies are closely linked, and thus have corporate bankruptcy systems that, while still unique, are amongst the most comparable of any two among the developed world. More generally, as shown throughout the paper, the strengths and weaknesses of each jurisdiction can inform the solutions we propose. Thus, we ultimately suggest that Canada would be well served by adopting certain aspects of U.S. law, and conversely the U.S. would increase the efficiency of its corporate bankruptcy system by taking insights from the Canadian system.

We begin by considering the US and Canadian law on involuntary creditors, particularly environmental claims, in corporate reorganization proceedings. As we show, the law in Canada is somewhat underdeveloped and vague, which leaves open the possibility of abuse by the controlling parties in a CCAA proceeding. On the other hand, while the law in the United States is more developed, it is not much clearer. This again puts the onus on environment regulators and other involuntary claimants to protect their interests.

As we ultimately show, to the extent these creditors are separately considered by US or Canadian bankruptcy systems, the focus is typically on the involuntary creditor's status as a claimholder in the proceeding. But in a world where debtors routinely pledge all of their assets to senior creditors before bankruptcy, and those assets are frequently liquidated before consideration of a bankruptcy plan, this puts the emphasis too late in the process.

We develop this argument in the second part of the paper, showing how the move to heavily pledged assets in turn facilitates creditor control of quick sales in corporate reorganization proceedings. These quick sales allow for the sale of assets free from involuntary claims in a way that would not be possible outside of bankruptcy, or often even under a formal reorganization

\footnotetext{
$6 \quad$ For a detailed comparative discussion of quick sales see Stephanie Ben-Ishai and Stephen Lubben, "Sales or Plans: A Comparative Account of the "New" Corporate Reorganization" (2011) 56 McGill L.J. 591 [Ben-Ishai \& Lubben, "Sales or Plans"].

$7 \quad 11$ U.S.C. $\$ 363(f)$. In re Trans World Airlines Inc., 322 F.3d 283 (3d Cir. 2003).
} 
plan. The risk that we identify is that this heightened power to sell assets also undermines the leverage of involuntary creditors, increasing the possibilities for senior lenders to transfer wealth to themselves.

In the third part of the paper, we consider how U.S. and Canadian procedures could be improved to guard against this risk.

We ultimately conclude that revising the U.S. and Canadian procedures to outlaw quick sales or limit them to cases where the debtor's assets are perishable is unlikely to be met with political approval in either jurisdiction or necessarily improve the outcome for involuntary creditors. However, as we have argued elsewhere in a more general comparison of the two regimes, this is another instance where it would be helpful to draw on key aspects of both systems. That is, the greater clarity provided for by the quick sale regime under chapter 11 and the more flexible newly developed test under the Canadian CCAA regime for approving quick sales. A more transparent version of the new CCAA test - that requires judicial balancing of interests - would provide a framework that involuntary creditors can begin to adjust to in the new reality of quick sales versus plans.

\section{The Law of Involuntary Creditors: A Comparative Account}

In this part, we develop an understanding of the law of involuntary creditors, with a particular focus on environmental creditors, whom we use as the prototypical example for the rest of the paper. But first, a definition: what is an involuntary creditor? Throughout the paper we use the term "involuntary creditor" to refer to any creditor that lacks the ability to protect itself ex ante. This inability is typically the result of a lack of information - tort creditors do not know they are or will be injured, environmental creditors do not have full information about the conditions on private property, and taxing authorities rely on debtors to provide information, and may only obtain the right to question that information years after liability has been created.

For purposes of this paper we do not consider creditors that do not contract to protect themselves as involuntary, even if the failure to contract is the understandable result of information or transaction costs. ${ }^{8}$ These "mal adjusting" creditors are likely to be the collateral beneficiaries of many of the reforms we propose in Part III, but they are not are primary focus, inasmuch as we focus on those parties that are affirmatively harmed by modern corporate reorganization practices.

In both the United States and Canada operating firms are subject to a variety of federal and state or provincial environmental regulations. In the US, CERCLA is the principal federal statute concerning the cleanup or remediation of historical environmental contamination. The statute gives the Environmental Protection Agency numerous administrative and judicial tools to address risks posed by historical contamination.

$8 \quad$ Lucian Arye Bebchuk \& Jesse M. Fried, "The Uneasy Case for the Priority of Secured Claims in Bankruptcy” (1996) 105 Yale L.J. 857 at 880-92. See also Lynn M. LoPucki, "The Unsecured Creditor's Bargain" (1994) 80 Va. L. Rev. 1887 at 1897. 
In addition to providing EPA with the authority to undertake response actions, CERCLA creates liability, based on a "polluter pays" principal. First, if EPA, or any other party, cleans up a property, that party can recover its costs from four categories of responsible parties: the present owner and operator of the facility from which the hazardous waste were released, the past owners and operators of those facilities at the time the release occurred, generators of hazardous substances who arranged for disposal of their wastes at the site, and haulers who took wastes to the site. ${ }^{9}$ In addition, EPA has authority to require responsible parties to perform cleanup actions themselves. ${ }^{10}$ Other federal statutes are generally similar in coverage, but sometimes provide for different or more limited remedies. For example, under the Resource Conservation and Recovery Act, the EPA can only seek injunctions or administrative orders requiring the responsible party to take action - monetary damages are not available. ${ }^{11}$

The Canadian approach is somewhat similar, insofar as there are checks in place designed to make the debtor company liable for the environmental damage and contamination it causes. Specifically, provincial and federal environmental protection statutes provide that a person who is in control of premises is liable for the costs of environmental remediation. ${ }^{12}$ This is what is known as the "polluter pays" principle in Canada, whereby the person who is responsible for the damage is held accountable.

Moreover both of Canada's principal insolvency statutes - the Bankruptcy and Insolvency Act and the Companies' Creditors Arrangement Act-incorporate rules governing environmental claims; however, within the insolvency context, it is worth noting that the usual environmental liability rules in federal and provincial legislation are modified, as will be discussed below. This contrasts with the United States, where environmental claims are not expressly mentioned in the Bankruptcy Code.

And despite the initial similarity between the Canadian and US regimes, the two jurisdictions differ in subtle ways with regard to how these cleanup obligations are treated upon insolvency. In the United States the debtor's liability for past cleanup work conducted by somebody else, whether the EPA or a private party, is a general unsecured claim that can be treated as such during the reorganization case. ${ }^{13}$ On the other hand, orders directing the debtor to clean up property are typically not considered claims, and as such are not discharged at the end of the debtor's case. ${ }^{14}$ This latter rule can apply to property that the debtor owned in the past, but no longer owns by the time of bankruptcy, and clearly gives the EPA a strong incentive to avoid taking on the cleanup work themselves. ${ }^{15}$

\footnotetext{
92 U.S.C.A. $\S 9607(\mathrm{a})$.

1042 U.S.C.A. $\$ 9606(\mathrm{a})$.

11

12 See, for example, Environmental Protection Act, R.S.O. 1990, c. E-19.

13 Ohio v. Kovacs, 469 U.S. 274 (1985).

$14 \quad$ United States v. Apex Oil Co., 579 F. $3 d 734$ (7th Cir. 2009); In re Chateaugay Corp., 944 F. 2 d 997 (2d Cir. 1991).

15 In re Torwico Electronics, Inc., 8 F. 3d 146 (3d Cir. 1993).
} 
In Canada, the environmental authorities have somewhat better protection for past remediation. This is because costs are secured by a security interest on the real property affected by the environmental conditions as well as on any contiguous real property and that interest is given super-priority status over any other claim, right, charge or security against the property. ${ }^{16}$ The source for this super-priority status is found in Canada's two principal insolvency and restructuring statute, the Bankruptcy and Insolvency Act (the "BIA") and the Companies" Creditors Arrangement Act (the "CCAA").

Specifically, under these Acts, any federal or provincial governmental claim against the debtor for the costs of remedying any environmental damage affecting the real property of the debtor is secured by a charge on that real property and any contiguous real property related to the activity that caused the damage. ${ }^{17}$ Under the Canadian Acts, the charge is enforceable in the same way as a mortgage or other security on real property, and is given super-priority over any other claim, right, charge or security on the property. ${ }^{18}$ Essentially, this amounts to a governmental "superlien" on the debtor's property and provides these involuntary claimants with a better priority status than what they would have received if the ordinary priority rules were applied. ${ }^{19}$

Under this scheme, the environmental condition or damage may occur before or after the date that the debtor files for bankruptcy or the date of filing a plan under the CCAA. ${ }^{20}$ It is worth noting that if the environmental damage is extensive, the costs of the clean up may be in excess of the value of the property; in such cases, compliance with the remediation order will diminish the value of the assets available to the other creditors who have a claim. ${ }^{21}$ However, the policy rationale behind these provisions is that the party in control of a property should be liable for the costs of any environmental remediation necessitated by their occupancy. Accordingly, the environmental remediation provisions in the BIA and CCAA reflect the "polluter pays" principle entrenched in federal and provincial incorporation legislation. ${ }^{22}$

With regard to presently contaminated property, the tables turn yet again, as the United States prohibits the abandonment of contaminated property in liquidation, ${ }^{23}$ and abandonment would seem to be pointless in a traditional reorganization, because all property revests in the debtor at the end of the chapter 11 case. $^{24}$ Whist in Canada, the trustee in bankruptcy or the CCAA

16 See s.11.8(8), CCAA.

17 Bankruptcy and Insolvency Act, R.S.C. 1985, c. B-3 at s.14.06(7) [BIA]; and Companies' Creditors Arrangement Act, R.S.C. 1985, c. C-36 [CCAA].

18 BIA, ibid; CCAA, ibid; and Roderick Wood, Bankruptcy and Insolvency Law (Toronto: Irwin Law, 2009) at 415-16 [Wood].

19 Alexandria Pike, "Environmental Issues in Insolvency: Recent Developments" (Davies, Ward, Phillips \& Vinerberg LLP, 13 December 2010) [Pike]; and Wood, ibid. at 488. BIA, ibid. at 14.06(8) and CCAA, ibid. at 11.8(9).

Wood, supra note 12 at 169.

Wood, ibid. at 141 . Midlantic National Bank v. New Jersey Department of Environmental Protection, 474 U.S. 494 (1986).

Anne M. Lawton \& Lynda J. Oswald, "Scary Stories and the Limited Liability Polluter in Chapter 11" (2008) 65 Wash. \& Lee L. Rev. 451, 475. 
monitor may abandon environmentally damaged property, subject to certain rules, ${ }^{25}$ and if this is done the monitor is not required to comply with a remediation order. ${ }^{26}$ Moreover, under the Canadian system, the trustee/monitor is not personally liable for any environmental condition that occurred either before their appointment, or even after, unless the damage or condition arose as a result of their gross negligence or misconduct. ${ }^{27}$

The Superior Court of Justice decision in General Chemical Canada Ltd., Re, ${ }^{28}$ provides an example of the Canadian approach. The Court considered the issue of environmental cleanup costs in the context of the bankruptcy of a chemical company. ${ }^{29}$ Although the Ministry of the Environment ("MOE") of Ontario had claimed entitlement to costs related to environmental clean-up of the debtor's property, the interim receiver for the bankrupt estate had also brought a motion of the interim distribution of the estate's assets. It is worth noting that the funds that the interim receiver sought to distribute came from the operation of the debtor's business, as opposed to real estate holdings. ${ }^{30}$ The Minister opposed the receiver's motion; specifically, despite conceding that any secured claim it had attached only to General Chemical's real property, it nevertheless maintained that both the debtor and the receiver had an obligation to take care of the cost of environmental cleanup before any funds were paid out to creditors. ${ }^{31}$

However, the court disagreed and granted the receiver's motion to distribute the assets, holding that the Minister was, in effect, an unsecured creditor who was not entitled to special priority for cleanup costs. $^{32}$ This was especially so given that the assets that generated funds were not connected to the property that had created the environmental damage; accordingly, the Minister had no lien or priority over these funds. In its decision, the court observed that the Environmental Protection Act permits the MOE to issue orders to a polluter to clean up polluted property. However, absent exceptional circumstances or gross negligence or misconduct on the part of the trustee or receiver, the MOE is prevented from issuing orders to trustees or receivers. ${ }^{33}$

Accordingly, this case established that the powers of the government to make environmental orders in the context of a bankruptcy is, in fact, limited. It also bears mentioning that in its

25 Specifically, the trustee must elect to abandon the property by providing notice to the authority who issued the order and, unless some other period is specified in the order, the election to abandon must occur within ten days after the order is made. See Wood, supra note 12 at 169. BIA, supra note 11 at s.14.06(4); and CCAA, supra note 11 at s.11.8(5). BIA, ibid. at s.14.06(2); and CCAA, ibid. at s.11.8(3). General Chemical Canada Ltd., Re, (2006) 22 C.B.R. $\left(5^{\text {th }}\right) 298$ [General Chemical Canada].

29 General Chemical Canada, ibid. at para. 17-18.

30 General Chemical Canada, ibid. at para. 1.

31 General Chemical Canada, ibid. at para. 34.

General Chemical Canada, ibid. at para. 46. The court went on to specify that, apart from its security, the MOE was an unsecured creditor like any other and "must prove its claim in the General Chemical bankruptcy. To permit the MOE to delay distribution to a secured creditor would give the MOE a quasipriority to other unsecured creditors, and would defeat or delay the legitimate interests of secured creditors." Ibid. at para. 46.

General Chemical Canada, ibid. at para. 40 (emphasis added). 
decision, the Court observed that the MOE's right to review General Chemical's financial assurance and require changes to it was stayed by the CCAA order-as General Chemical had first tried to reorganize under the CCAA, before failing to do so and filing for bankruptcy. ${ }^{34}$

In the appeal of General Chemical Canada Ltd., $R e,{ }^{35}$ the debtor's interim receiver proposed a plan that was opposed by the MOE, on the grounds that the debtor failed to comply with provincial environmental safety requirements. As a result of this failure, the MOE claimed that there would be significant cleanup costs that exceeded the debtor's financial assurance under the Environmental Protection Act. ${ }^{36}$ In this case, it was the MOE's position that the "polluter pays" principle for environmental remediation required that no distribution take place until there is an assurance that the debtor's assets are sufficient to effect a cleanup. ${ }^{37}$ However, the Court found that in the face of BIA s.14.06(7) — which provides for priority to be accorded to environmental clean up costs - and s.14.06(8) - which establishes that environmental cleanup costs are provable claims in bankruptcy - the provincial environmental legislation was of no effect. ${ }^{38}$ Specifically, the federal bankruptcy legislation was held to be paramount over the provincial regulations that the MOE was seeking to enforce. The Court went on to hold that MOE was merely an unsecured creditor - albeit one that had security over the debtor's real property, as provided for in the BIA. ${ }^{39}$ As such, the interim receiver was allowed to proceed with distributing the assets of the estate.

Before reaching the facile conclusion that the Canadian approach favours past cleanup, while the American approach is better suited to protect unaddressed contamination, let us provide a few complicating factors. First, the inability of a liquidating American debtor to abandon contaminated property is of little consequence if the debtor has no ability to pay to clean up the property. Second, the Canadian super-priority lien is simply that - a super-priority lien in a contaminated property. The ability to foreclose on such a property is unlikely to be attractive.

Thus, the utility of each of these protections is apt to turn on the debtor's need for the contaminated property, and the environmental claimant's ability to turn that need into leverage in the reorganization process. But as we discuss in the next section, new developments in corporate reorganization practice in both the U.S. and Canada tend to undermine this power.

\section{Involuntary Creditors in the "New" Corporate Bankruptcy}

Traditional corporate reorganization involves the acceptance of a plan by creditors, with a concomitant reduction of the debtor's fixed claims and realignment of its operations. In the United States, this process is facilitated by an automatic stay of actions against the debtor, ${ }^{40}$ and

\footnotetext{
$34 \quad$ General Chemical Canada, ibid. at para. 21.

35 General Chemical Canada Ltd., Re, 2007 ONCA 600, 228 O.A.C. 385 [General Chemical Appeal].

36 Environmental Protection Act, R.S.O. 1990, c.E.19.

$37 \quad$ General Chemical Appeal, supra note 35 at para. 43.

38 General Chemical Appeal, ibid. at para. 46.

39 General Chemical Appeal, ibid. at para. 47.

$40 \quad 11$ U.S.C. $\S 362$.
} 
a similar stay is typically entered in Canadian CCAA proceedings. ${ }^{41}$ In chapter 11 unsecured creditors are typically represented by a committee, ${ }^{42}$ while in CCAA this role is taken up by the monitor. ${ }^{43}$ The debtor formulates a plan, and the creditors then vote on the same. ${ }^{44}$ After the creditors approve the plan, the court will consider the plan and, if it meets the provisions of the statute, sanction it and it becomes binding on all claimants. ${ }^{45}$

This traditional form of corporate bankruptcy is increasingly rare in larger corporate insolvency cases. $^{46}$ Instead, debtors utilize their power to sell their assets first, and then proceed to formulate a plan that distributes the sale proceeds to creditors. ${ }^{47}$

Take, for example, the well-known case of Lehman Brothers. The Lehman holding company filed under chapter 11 in New York on September 15, 2008, and sold office buildings and the North American investment-banking business to Barclays one week later. It continues to work toward a plan that will distribute the proceeds of this and other asset sales.

This change in approach has been attributed to the growing power of secured lenders. ${ }^{48}$ This is particularly true in the United States, where it is argued that secured lenders have learned the lessons of the Eastern Airlines case - an major airline case from the 1980s that is said to typify debtor control, and which ultimately resulted in the eventual liquidation of Eastern - and now understand how they can use their pre-bankruptcy power over the debtor's liquidity to control the chapter 11 process. $^{49}$

But this is more a story of how, than why. Aside from the implicit benefits of avoiding a lengthy reorganization process, ${ }^{50}$ the reasons for why this turn to quick sales has happened, and whether

\footnotetext{
41 CCAA, s. 11.03.

$42 \quad 11$ U.S.C. $\S \S 1102-1103$.

43 CCAA s.11(7).

$44 \quad$ CCAA, s. 6(1); 11 U.S.C. $\S \S 1121,1126$.

45 CCAA, s. 6(1); 11 U.S.C. $\S 1129$.
}

$46 \quad$ Ben-Ishai \& Lubben, supra note 6. See also In re Chrysler, 576 F.3d 108, 115 (2d Cir. 2009) (citing Douglas G. Baird \& Robert K. Rasmussen, “The End of Bankruptcy” (2002) 55 Stan. L. Rev. 751, 751-52, vacated as moot, 130 S.Ct. 1510 (2009).

47 CCAA. s. 36; 11 U.S.C. § 363. See Stephanie Ben-Ishai, Bankruptcy Reforms: 2008 (Toronto: Thomson Carswell, 2008) at 59.

48 Jay Lawrence Westbrook, “The Control of Wealth in Bankruptcy” (2005) 82 Tex. L. Rev. 795.

49 See, e.g., Douglas G. Baird \& Robert K. Rasmussen, “The End of Bankruptcy” (2002) 55 Stan. L. Rev. 751.

50 But see Lynn M. LoPucki and Joseph W. Doherty, Professional Fees in Corporate Bankruptcies: Data, Analysis, and Evaluation (Oxford University Press 2011) (finding that $\$ 363$ do not actually cost much less in terms of professional fees). 
it benefits anyone besides the senior lenders, is still open to debate. ${ }^{51}$ And some argue that the trend is affirmatively harmful to the goal of maximizing the value of the debtor. ${ }^{52}$

The nearest thing to a normative justification for quick sales has been Baird and Rasmussen's argument that current American chapter 11 debtors generally lack substantial debtor-specific value, and thus sale of these assets is apt to realize as much as any reorganization of the same. ${ }^{53}$ This "no harm, no foul" argument was very likely a product of the specific time when Baird and Rasmussen wrote their papers: during the early part of this century the American bankruptcy system was still dealing with the remnants of the "tech bubble" of the late 1990s, meaning that many debtors of that era had fewer fixed assets than before, and, as we now know all too well, there was also a simultaneous credit bubble that allowed for purchasers to easily finance the acquisition of distressed assets, which no doubt reduced the risk that quick sales would result in reduced prices. ${ }^{54}$

In this paper we present a new justification for quick sales that turns on the presence of involuntary creditors, especially environmental claims. Especially in the United States, as we develop further below, the existing case law on environmental claims in reorganization proceedings strongly encourages the breakup of the firm: with untainted assets transferred to a new owner, while the old debtor liquidates the contaminated property along with a distribution of the sale proceeds.

In Canada a similar set of issues are at stake, although the law is less developed on this point, especially since the asset sale provision of the CCAA is relatively new, its current form only coming into being with the 2009 reforms to the CCAA. In the past, without any express provisions dealing with asset sales in the CCAA, Canadian courts relied on their powers to impose terms and conditions under a stay order. ${ }^{55}$

The tendency to move toward sales as opposed to reorganization plans is driven by two related factors: the focus on environmental obligations' status as "claims," and the development in both chapter 11 and the CCAA of a strong ability to sell assets "free and clear" of charges on those assets.

The question of whether an environmental obligation is a claim has been particularly significant in the United States, but the apparent victory of environmental regulators on this point is apt to be hollow, for it depends on the debtor's continued operations post-insolvency. And the growing strength of sale orders, transferring assets free and clear of obligations, means that the debtor and its controlling creditors are increasingly unconcerned about the ability to obtain a discharge at the end of the reorganization process. As the discharge losses it significance, the power of involuntary creditors is apt to dwindle.

$51 \quad$ Stephen J. Lubben, “The 'New and Improved' Chapter 11” (2005) 93 Ky. L.J. 839; See also George W. Kuney, "Hijacking Chapter 11” (2004) 21 Emory Bankr. Dev. J. 19, 111.

52 Lynn M. LoPucki \& Joseph W. Doherty, "Bankruptcy Fire Sales” (2007) 106 Mich. L. Rev. 1.

53 Douglas G. Baird \& Robert K. Rasmussen, “Chapter 11 at Twilight” (2003) 56 Stan. L. Rev. 673.

$54 \quad$ Harvey R. Miller \& Shai Y. Waisman, “Is Chapter 11 Bankrupt?” (2005) 47 B.C.L. Rev. $129,156$.

55 Under s.11 of the CCAA. 


\section{A. Environmental "Claims"}

The U.S. Bankruptcy Code provides that the confirmation of a chapter 11 plan "discharges" the debtor from any debt -- defined as "liability on a claim" -- that "arose" before the date of confirmation. ${ }^{56}$ A "claim" in turn is defined to include both a "right to payment" and a "right to an equitable remedy for breach of performance if such breach gives rise to a right to payment." Under the Bankruptcy Code, a discharge "operates as an injunction against the commencement or continuation of an action, the employment of process, or an act, to collect, recover or offset any such debt as a personal liability of the debtor." 58

In the environmental context, a court must therefore determine whether an obligation for environmental cleanup liability constitutes a pre-petition "claim." than thirty years of litigation tells us the pre-bankruptcy obligations to pay for past cleanup are dischargeable, ${ }^{60}$ so long as the discharge comes after the enactment of the relevant environmental statute ${ }^{61}$ while the duty to comply with environmental regulatory laws and cleanup currently contaminated property is not dischargeable. ${ }^{62}$ Thus cleanup obligations imposed on owners of contaminated land under CERCLA run with the land and will not be discharged in bankruptcy. ${ }^{63}$

In Canada, both the BIA and CCAA establish that environmental claims constitute "provable claims" in bankruptcy. Specifically, under s.14.06(8) of the BIA and s.11.8(9) of the CCAA, a claim against the debtor company for the costs of remedying any environmental conditions or environmental damage affecting real property or an immovable of the debtor shall be a provable claim, regardless of whether the condition arose or the damage occurred before or after the date of the filing under which proceedings were commenced under both those Acts. ${ }^{64}$

The provability issue was explored in Newfoundland and Labrador v. Abitibibowater Inc., ${ }^{65}$ where the topic of environmental cleanup costs was broached by the Quebec Court of Appeal. Here, the Minister of Environment and Conservation of Newfoundland and Labrador issued five ministerial orders ("EPA orders") against the debtor, mandating the complete environmental remediation of sites where it had conducted large-scale industrial activities. ${ }^{66}$ At the time when

$56 \quad 11$ U.S.C. $\S 101(12)$.

$57 \quad 11$ U.S.C. $\S 101(5)$.

$58 \quad 11$ U.S.C. $\S 524$.

59 Robert P. Frank, "Liability without end? The discharge of CERCLA liability in bankruptcy after Atlantic Research" (2010) 21 Fordham Envtl. L. Rev. 559, 564-66.

$60 \quad$ Ohio v. Kovacs, 469 U.S. 274 (1985). See also Boston and Maine Corp. v. Mass. Bay Transp. Auth., 587 F.3d 89 (1st Cir. 2009).

$61 \quad$ In re Penn Central Transportation Co., 944 F.2d 164 (3d Cir. 1991).

62 In re Torwico Electronics, Inc., 8 F.3d 146 (3d Cir. 1993).

In re CMC Heartland Partners, 966 F.2d 1143 (7th Cir. 1992).

64 BIA, supra note 11 at s.14.06(8); and CCAA, supra note 11 at s.11.8(9). See also, General Chemical Canada Ltd., Re, 2007 ONCA 600, 228 O.A.C. 385 at para. 46.

65 Newfoundland and Labrador v. Abitibibowater Inc., 2010 QCAA 965 [AbitibiBowater Appeal]. 
the orders were issued, however, the debtor had already filed for protection under the CCAA. A claims procedure order was then made, directing the debtor's creditors to file their proofs claim by the claims bar date. In response, the province argued that the statutory duty to remediate contaminated property could not be considered a "claim" under the claims procedure or the CCAA; thus, the EPA orders were not affected by the claims bar process. However, the provincial superior court and court of appeal both dismissed the province's motion. Most recently, the Supreme Court of Canada granted the province leave to appeal in this matter. ${ }^{67}$

In the US, non-dischargability of environmental orders means that orders to clean up property can continue to be enforced during, ${ }^{68}$ and after the debtor's reorganization case. ${ }^{69}$ Moreover, as an ongoing obligation, the duty to remediate may be entitled to be characterized as an expense of administering the reorganization. ${ }^{70}$ Under chapter 11 , such expenses must be paid in full, in cash before a reorganization plan can be confirmed by the court. ${ }^{71}$

In Canada, this is not necessarily the case. Rather, Canadian courts have held that environmental cleanup costs can be compromised during the restructuring process, and therefore do not have to be paid in full before a plan of arrangement or compromise can be approved the court. For example, in AbitibiBowater Inc., Re ${ }^{72}$ the Quebec Court of Appeal upheld a lower court decision that provincial environmental claims against the debtor were simply financial in nature and should therefore be treated as ordinary claims under the CCAA, which are subject to compromise under the Act.

In that case, the debtor-Abitibi - was one of the world's largest publicly traded pulp and paper companies, and had carried on industrial activities at several locations in Quebec. ${ }^{73}$ Shortly after the debtor filed under the $\mathrm{CCAA},{ }^{74}$ the province, pursuant to the Environmental Protection Act, issued several ministerial orders requesting the company perform remediation on the land the where the company had carried on industrial activities. The province brought a motion seeking a declaration that the orders were not affected by the CCAA proceedings and not stayed the initial order under the CCAA. ${ }^{75}$ Yet, the judge who heard the motions hearing held that the orders were financial in nature and should therefore be treated as claims under the CCAA and subject to

67 Newfoundland and Labrador v. Abitibibowater Inc., [2010] S.C.C.A. 269. Safety-Kleen, Inc. v. Wyche, 274 F.3d 846 (4th Cir. 2001); United States v. Nicolet, Inc., 857 F.2d 267 (3d Cir. 1988).

Chateaugay Corp. v. LTV Corp. (In re Chateaugay Corp.), 944 F.2d 997 (2d Cir. 1991). See also U.S. v. Apex Oil Co., Inc., 579 F.3d 734 (7th Cir. 2009), cert. denied, 2010 WL 752322 (2010).

In re Wall Tube \& Metal Products Co., 831 F.2d 118 (6th Cir. 1987). The "actual, necessary costs and expenses of preserving [the] estate," are entitled to administrative expense status and have a first priority in payment. 11 U.S.C. $\S \S 507(a)(1), 503(b)(1)(a)$.

11 U.S.C. $\$ 1129(a)(9)(A)$.

AbitibiBowater Inc. Re, 2010 QCCA 965, 68 C.B.R. (5th) 57 [AbitibiBowater Appeal].

AbitibiBowater Appeal, ibid. at paras. 2-3.

AbitibiBowater Appeal, ibid. at paras. 4, 7.

AbitibiBowater Appeal, ibid. at paras. 14-15. 
compromise. ${ }^{76}$ The province appealed this decision, but the appellate judge upheld the motion judge's findings, holding that his decision did not immunize the company from compliance with environmental orders; rather, his decision merely characterized them in the context of the restructuring process engaged pursuant to the CCAA. ${ }^{77}$ Although this case did not specifically touch on the ability to discharge environmental claims under the CCAA, the Court's insistence that these claims be treated as any other financial claims under the Act - and be subject to compromise accordingly — hints that these claims would also be discharged in the same manner as other financial claims under the Act. The manner in which environmental remediation claims are treated in Canada is distinct from the way they are dealt with in the U.S., insofar as these claims do not necessarily have to be paid in full in Canada.

In short, having won the battle to determine that environmental obligations are not prebankruptcy "claims," environmental regulators in the US seemly obtained a privileged position for these types of involuntary claims. The claims continue to be enforceable against the debtor, despite the bankruptcy, and must be paid in full before the debtor can leave chapter $11 .^{78}$ The situation is more uncertain in Canada and Abitibi suggests that such claims would not continue to be enforceable against the debtor.

But this assumes that the debtor's goal is to leave reorganization and resume normal operations, and that the only way to do that is at the end of its case. But a sale of the debtor's assets to a new entity - less any contaminated assets - can achieve the same result, without implicating the "victory" environmental regulators seemingly won when they avoided having their claims subjected to the bankruptcy process.

Indeed, it would seem that American environmental regulators placed too much focus on the continued existence of the debtor as a specific legal entity. The ability to assert an administrative claim that is entitled to be paid in full only matters if the debtor intends to propose a plan, and the ability to assert a claim against the debtor after bankruptcy only works if the debtor will be around after bankruptcy.

But if the debtor can achieve the equivalent of reorganization by selling its uncontaminated assets to a new legal entity, that will quickly adopt the debtor's old name, then there is no need to follow all the steps of a traditional reorganization. Instead, the debtor will happily leave the remnant bits of its former self to face liquidation or even abandonment.

The key to the debtor's ability to do this turns on the CCAA and Bankruptcy Code's provisions providing for sales "free and clear" of prior claims, which we turn to next.

\section{B. Sale as a Discharge Substitute}

$76 \quad$ AbitibiBowater Appeal, ibid. at para. 22.

$77 \quad$ AbitibiBowater Appeal, ibid. at para. 33.

$78 \quad$ In re General Motors Corp., 407 B.R. 463 at 505 (Bankr. S.D.N.Y. 2009) ("the purchaser would have to comply with its environmental responsibilities starting with the day it got the property, and if the property required remediation as of that time, any such remediation would be the buyer's responsibility"). 
If a debtor stays largely intact during its reorganization, the scope of its discharge at the end of the CCAA or chapter 11 process is key. But if the debtor sells most of its assets, discharge wanes in importance. And if the debtor can create a new entity to buy its assets, then the distinction between "normal" reorganization and sale vanishes from an operational perspective, and the only question is which process better rids the assets of past errors, thus maximizing the value of the same.

Outside of reorganization, the general rule is that an asset sale does not result in a transfer of liabilities, unlike a merger. ${ }^{79}$ But several other doctrines limit the general rule. For example, in many jurisdictions in the United States, courts have developed successor liability doctrines that lead to continued liability for a purchaser for products defects. Moreover, a buyer outside of reorganization takes subject to the risk that the transaction will be challenged ex post as a fraudulent transfer, if the debtor is deemed to have sold its assets "too cheap."

Thus, in the chapter 11 or CCAA sale context, the vital feature of reorganization law is the ability to sell assets free and clear of claims to the buyer. For example, section 363(f) of the Bankruptcy Code authorizes the trustee or a debtor in possession to sell property of a debtor "free and clear of any interest in such property." An interest in property includes "claims" that arise from the assets being sold.

Essentially, § 363(f) authorizes the bankruptcy court to grant relief similar to the discharge enjoyed by debtors under the Code, exonerating a buyer from successor liability, including liability for the debtor's environmental claims that are unrelated to the purchased assets. The CCAA allows for similar protection, authorizing a court to order that the property be sold to the purchaser free and clear of charges, liens and restrictions. ${ }^{80}$

This includes the environmental claims that the debtor owes, so long as the purchased assets do not include contaminated assets. Thus, General Motors sold its 'good' assets to a newly created company and its surviving business is now free of any obligations for its formerly owned contaminated properties. Creditors could file claims in the bankruptcy case and perhaps get small distributions, but the new company called GM is free of these obligations. ${ }^{81}$ Accordingly, it is possible - as long as the debtor company does not sell its contaminated property - for a debtor subject to environmental claims to effect a sale of its assets, largely free and clear for charges liens and restrictions.

In Canada, this has been held to mean that an interim receiver can distribute the assets of the debtor's estate, as long as those assets are business assets, as opposed the real property subject to contaminated-related liens by the federal or provincial government. For instance, as discussed earlier, in General Chemical, the Ontario Court of Appeal examined the issue of selling the debtor's assets when they are subject to an environmental claim. ${ }^{82}$ Here, the interim receiver sought approval for a sale of the debtor's assets, while the MOE opposed the distribution on the

\footnotetext{
79 Compare Delaware General Corporation Law $§ 271$ with $§ 253$.

80 CCAA, s. 36(6).

81 The US EPA filed a claim for more than $\$ 2$ billion in the "old" GM chapter 11 case.

82 General Chemical Canada Ltd., Re 2007 ONCA 600, 228 O.A.C. 385.
} 
grounds that the debtor had contaminated the site of one of its plants, and the remediation costs for cleaning up this contamination were estimated to be quite high; accordingly, the province was anxious to have the assets of General Chemical available to pay for this clean up. ${ }^{83}$

However, in this instance, the assets that the receiver was looking to sell were those from the operation of debtor's business and not the debtor's contaminated real property, over which the province has super-priority under the $B I A$ and $C C A A$. As such, the court held that the province did not have a security interest in General Chemical's operating assets. ${ }^{84}$ Accordingly, the sale of the debtor's assets was allowed on the facts of this case.

In contrast, part of the AbitibiBowater case dealt with the sale of several contaminated waste disposal sites. In a factum by the Province of Ontario, submitted to the Quebec Superior Court, the province opposed Abitibi's motion for an order authorizing the sale of these contaminated sites, on the basis that it was not in the public interest to do so. ${ }^{85}$ Specifically, the Province argued that the sale was contrary to the public interest since the effect of the sale would be to authorize the debtor to shed its regulatory environmental responsibilities in respect of its waste disposal sites; moreover, the Province alleged that there was no evidence that if the sale was disallowed that the CCAA reorganization of Abitibi would fail. This is important in light of the fact that section 36 of the CCAA now requires a debtor company to obtain the authorization of a court before selling its assets outside of the ordinary course of business; one of the key factors to be considered by the court is making such a determination is "the effect of the proposed sale or disposition on the creditors and other interested parties," including the public. ${ }^{86}$ Accordingly, this factum not only hints that the test upon which asset sales should be judged is whether, if denied, there is a reasonable prospect that the restructuring will fail; the Province's claims also imply that there should be a distinction between the sale of real property and the sale of operating assets when a debtor is subject to environmental claims.

Notice, however, that this case reverses the typical structure, particularly in the United States, where the debtor wants to sell everything but the contaminated property. In such a situation, the environmental claimant has two options: object to the sale or seek to obtain a priority claim against the sale proceeds. The first strategy is often the reflexive position of environmental claimants, but is only useful if the claimant considers the question of what will happen if it succeeds. In particular, blocking a sale to force a liquidation of the debtor is both socially inefficient and unlikely to benefit the objecting claimant. The second strategy, seeking priority access to the sale proceeds, will likely place the environmental creditor in competition with senior, secured creditors. Both these strategies are examined in the larger context of modern corporate reorganization practice, in the next part of the paper.

\footnotetext{
83 General Chemical, ibid. at para. 38.

$84 \quad$ General Chemical, ibid. at para. 42.

85 In the Matter of the Plan of Compromise or Arrangement of AbitibiBowater Inc. (Court File No. 500-11036133-094) at paras. 1-2 [Abitibi Factum]. 


\section{Adjusting to the New Reality}

If debtors with environmental obligations and other involuntary obligations increasingly turn to quick sales to realize the value of their assets, then strategies designed to exempt environmental claims and other involuntary debt claims from the bankruptcy or insolvency process are no longer viable. Environmental claimants and other involuntary creditors will increasingly have to work within the insolvency system to protect their interests. Any attempt by the judiciary to continue to operate under the "old regime" will distort the current framework and have significant implications for the lending market as well as the ultimate objective of maximizing value available to all creditors.

But before proceeding, it makes some sense to consider if the solution to the problem of involuntary creditors under a regime of quick sales might not be addressed by simply prohibiting quick sales or limiting them to cases were the debtor's assets are literally perishable, an idea that traces back to the United States Bankruptcy Act of 1867 and was the rule in the United States before the enactment of the current Bankruptcy Code in 1978: pre-plan assets sales were only permitted in cases involving debtors with inventory of dairy products or vegetables, or where some other similar factor prevented the debtor from selling the assets as part of a full plan. ${ }^{87}$

Such a rule might make sense if we assume that the bulk of the current quick sales are substitutes for full reorganization cases. If, however, many current quick sales substitute for liquidations, the desirability of such a rule becomes rather suspect. And for a court faced with a debtor that asserts it will have to liquidate if it does not sell key assets quickly, the question of which type of debtor this might be is fraught with serious consequences, particularly if the court guesses wrong. Moreover, adopting a blanket rule against quick sales without understanding the larger empirical question of which type of debtor predominates would seem to be equally problematic.

In this context, we argue that the naïve solution of preventing quick sales is unlikely to prevail, and creditors, including involuntary creditors, thus need to adapt to the new reality. ${ }^{88}$ And the reorganization process itself needs to adapt to ensure that the process is being used to maximize the value of the debtor's assets, and not merely to transfer wealth among claimants.

To understand the necessary adaptions, it helps to begin with an exposition of precisely how a reorganization scheme based around quick assets sales could harm involuntary creditors. It is not a harm to creditors, voluntary or involuntary, that a sale results in little or no recovery for unsecured creditors, or shareholders. Rather the key issue is whether the sale results in the realization of less value by junior claimants than a traditional reorganization or liquidation.

A sale thus could result in the realization of equal value, but see that value diverted to senior creditors. This is a problem of redistribution. Some of the more nefarious versions of this

$87 \quad$ In re Solar Mfg. Corp., 176 F.2d 493 (3d Cir. 1949); In re V. Loewer's Gambrinus Brewery Co., 141 F.2d 747 (2d Cir. 1944).

88 See Stephen J. Lubben, "No Big Deal: The GM and Chrysler Cases in Context” (2009) 83 Am. Bank. L.J. $531,535-538$. 
problem have already been well ventilated in the literature, particularly in the United States. Thus, there is real concern that the sale process might facilitate collusion between management and senior creditors to squeeze out junior creditors and shareholders.

But the sale process also reduces the holdout powers that junior creditors have in a more formal reorganization. For example, a chapter 11 plan can only be confirmed - even under the "cramdown" power that allows plans to overcome creditor objections - if the plan has been accepted by one class of impaired creditors. ${ }^{89}$ A plan that pays secured creditors in full but leaves unsecured creditors with little or nothing might be rejected by the unsecured creditors, leaving the plan without an accepting impaired class. ${ }^{90}$ But the same transaction conducted as a sale could well be approved over the objection of creditors.

Similarly, if a clean-up obligation is a post-petition "administrative claim," the claimant has the right to demand payment in full before the debtor's plan can be confirmed. ${ }^{91}$ On the other hand, it is possible for the debtor to sell its assets without providing for full payment of administrative claims - although conversion to chapter 7 or dismissal of the case might be a likely result postsale.

In both instances, the junior creditors loose power, and thus value, by the move from plans to sales. It may be that from a policy perspective the value junior claimants loose in these latter examples result in a net efficiency gain - for example, if the junior creditors' right to impede a plan is nothing more than the power to extort rents for senior creditors, the ability to sidestep the holdup power through a sale is a good thing.

But a system of corporate reorganization is a system of checks and balances, and one should be hesitant to throw away one of those checks on the simple grounds of expediency. Whether the junior creditors are simply extracting value they are not entitled to, or whether they are putting the stop to senior creditor overreaching, is an unanswered empirical question. And while some junior creditors can price senior creditor expropriation ex ante, involuntary creditors like environmental claimants cannot.

At this point it is also important to consider efficiency from a somewhat broader perspective than is typical in much of the bankruptcy literature. In particular, while a particular creditor's decision to block the debtor's plan might seem inefficient within the internal context of insolvency law, from a broader societal perspective it might be that reorganization in the face of unpaid and unaddressed environmental claims is actually overall inefficient. At the same time, and as will be discussed more fully below, it might be that these larger issues are better served in some way other than a power to block the debtor's reorganization.

A sale might also result in lost value if the structure of the sale is such that is depresses the value of the debtor's assets. For example, if the sale is rushed or conducted in a way that discourages competitive bidding, the sale might not realize full value for the claimants. Value is not being

\begin{tabular}{ll}
\hline 89 & 11 U.S.C. $\$ 1129(a)(10)$. \\
90 & 11 U.S.C. $\$ 1126(f)$. \\
91 & 11 U.S.C. $\$ 1129(a)(9)$.
\end{tabular}


redirected, rather it is simply lost to the parties to the reorganization. Presumably the buyer of the assets realizes the value by obtaining a bargain price.

Senior lenders arguably do not have an incentive to control this issue unless the structural problems are so severe that they threaten senior claimants' recoveries. ${ }^{92}$ However, it is important in this context to distinguish between depressed value that results from generally distressed asset prices in the industry, as opposed to debtor-specific asset price depression caused by the sale itself.

The senior lender's ability to "credit bid" their secured claim as sale consideration will provide some check against a sale that undervalues the debtor, ${ }^{93}$ but it also suggests that in some cases the distinction between value diversion and value loss will be hard to perceive. If the debtor sets up a faulty sale process, that allows the senior lender to take the debtor's assets at a discount, the two flavours of sale problems meet in the middle.

Thus an involuntary creditor, like an environmental claimant, needs to consider two related types of harm that comes from the use of a sale in place of a plan: the sale to an outsider at less than full value and the sale to the senior creditor at less than full value. An involuntary creditor might also worry about their loss of holdup power, and that is a concern if that power prevents socially inefficient asset transfers.

In the latter case, the inefficiencies primarily arise from the debtor externalizing the cost of its environmental contamination. The beneficiary of this is primarily the senior lenders, who receive the sale proceeds.

This suggests that Canada might be on the right track when it provides environmental claims with a superpriority. But maybe it does not go far enough. In particular maybe the superpriority claim needs to be against the debtor's enterprise, rather than the particular piece of contaminated property. And note that such a superpriority works even in cases where the lender is oversecured and would otherwise be inclined to underinvest in monitoring the debtor, since the superpriority puts the lenders' equity cushion at risk.

But broad notions of enterprise liability are probably more apt to be academic than real, especially given the threat any such argument would pose to asset-backed securitization. ${ }^{94}$ The United States might consider adopting at least the Canadian version of the superpriority rule.

And there might be some room to construct a middle-ground mechanism to address the issue of unpaid environmental liabilities in the corporate group. For example, under US banking law, regulators have the power to require financial distressed banks to obtain contractual capital

92 A. Mechele Dickerson, "Words That Wound: Defining, Discussing, and Defeating Bankruptcy 'Corruption"” (2006) 54 Buff. L. Rev. 365, 370 n.14.

$93 \quad 11$ U.S.C. $\$ 363(\mathrm{k})$.

94 An insurance or bonding scheme might also seem like an obvious solution, but we worry that such a system is subject to the same information constraints that prevent an involuntary creditor from pricing the risk of non-payment in the first instance. Only an over-inclusive insurance or bonding requirement would seem able to overcome this problem. 
commitments from their parent companies. ${ }^{95}$ These agreements, which imposed fixed potential liabilities on the parent company are then subject to special priority status in the parent's subsequent bankruptcy case. ${ }^{96}$ A similar model might work with regard to environmental claims.

Adopting an expanded version of the Canadian superpriority or contracting for parent-company liability takes care of the problem of debtors that transfer value from environmental claimants to senior lenders, but there remains the problem of debtors who sell their assets too cheaply. This latter effect amounts to a transfer from junior creditors, including any involuntary creditors who do not benefit from a superpriority.

It can be expected that banks and other financial institutions will argue that a broadening of the superpriority - or the creation of it, in the case of the United States - will discourage lending to companies that have any connection with environmental pollution. But in part that is exactly the point: make companies internalize the cost of they impose on involuntary creditors, like environmental claimants. This issue was front and centre with respect to a different type of involuntary creditor - pension claimants - in a recent Ontario Court of Appeal decision.

Re Indalex Limited $^{97}$ concerned a cross-border proceeding where Indalex filed for CCAA protection in Canada and Indalex's parent companies and US based affiliates sought Chapter 11 protection in the US. The Canadian company was sold through a quick sale in the CCAA proceedings but the sale proceeds were insufficient to repay the DIP lenders. The US parent company covered the shortfall, in accordance with its obligations under a guarantee. At issue in the Court of Appeal decision was who as between the US parent company and the pension plan beneficiaries could claim the money from the sale proceeds held by the monitor in a reserve fund. The US parent claimed the funds based on its payment under the guarantee and the pension plan beneficiaries claimed the money based on deemed trust provisions in the provincial pension legislation.

Justice Gillese concluded that the deemed trust continued to operate under provincial law and stood ahead of the DIP lenders super-priority. In addition, she held that the employer had breached its fiduciary duties by wearing two hats as administrator of the pension plans with fiduciary duties to the pension plan beneficiaries and also as a corporation with a duty to act in the best interests of the corporation. The remedy for this breach was a constructive trust in favour of the pension plan beneficiaries.

In rendering her decision in Indalex, Justice Gillese was not prepared to address the issue of adapting to the new corporate reorganization model of quick sales and the impact of expanding priority for involuntary creditors in this context. She observed that the case concerned a liquidating CCAA and that there was no restructuring of the company. However, she was not prepared to consider how such a reality should be taken into account in dealing with unpaid pension obligations.

\begin{tabular}{ll}
\hline 95 & 12 U.S.C. $\$ 1831 \mathrm{o}(\mathrm{e})(2)$. \\
96 & 11 U.S.C. $\$ 507(\mathrm{a})(9)$. \\
97 & 2011 ONCA 265 ("Indalex").
\end{tabular}


Leave to appeal to the Supreme Court of Canada is currently being sought from Indalex. Already comments from number of the top Canadian law firms suggests that lending has been impacted by the decision and deals have been put on hold.

While Justice Gillese is convinced that Canadian corporate law duties force directors of a corporation on the cusp of a CCAA filing to consider the broader societal like concerns, she does not propose solution for how the uncertainty around super-priority created by her decision can be dealt with. That is, even CCAAs that result in quick sales require a DIP lender to fund the process.

A better point in time to consider whether and how a quick sale will impact involuntary creditors, like the pension claimants in Indalex, is the new section 36 process for approval by the court of a quick sale. Priorities need to be clear and not altered on a case-by-case basis.

More generally, to the extent there exists a gap between the private, internal efficiency of reorganization case and questions of social efficiency, which are of sufficient nuance that they can not be addressed by statute ex ante, there needs to be a mechanism to place such questions before court. This is one area where the Canadian monitor, who is no beholden to any particular stakeholder in the case, might provide a better tool than its American counterpart. Specifically, it cannot be expected that a creditors committee will consider issues beyond the class it represents.

On the other hand, consideration has to be given to the structure of the sale process itself. In particular, safeguards have to be in place to protect against collusion between the debtor's management and senior lenders. In this regard, the tendency to subject deals to "higher and better" offers, much more common in the United States than Canada, is a step in the right direction. But there is still a need for vigilance against sale structures that are auctions in name only.

\section{Conclusion}

We have identified three key issues that must be dealt with in the context of the treatment of involuntary creditors and the new reality of quick sales in reorganizations under the CCAA and Chapter 11:

a) Involuntary creditors loose the ability to object;

b) Quick sales may result in lost value that could have gone to involuntary creditors; and

c) Broader issues of efficiency and externalities.

As we have already suggested, the appropriate response to these concerns must be clear and consistent and not result in uncertainty around priorities of voluntary creditors. The following responses may be considered: 
a) The monitor or the US creditor committees may be a proxy for the lost voice of involuntary creditors. In addition, representative counsel, appointed by the court and paid for by the estate of the debtor may fulfill this role.

b) The requirement of an auction in "non-emergency" situations to ensure that value is not lost that could potentially have gone to the involuntary creditors.

c) The requirements that the public interest is considered in the section 36 sale process test may serve as an example of how externalities and broader efficiency related issues may be considered at an early stage in the process. 